\title{
Information Seeking Behavior of College Students During the Pandemic Covid-19: Case Study at Bukit Parung Asri Housing
}

\author{
$1^{\text {st }}$ Putri Dwi Novia ${ }^{1}, 2^{\text {nd }}$ Dewi Khairani ${ }^{2}, 3^{\text {rd }}$ Kamarusdiana $^{3}, 4^{\text {th }}$ Kusmana $^{4}$, \\ $5^{\text {th }}$ Sururin $^{5}, 6^{\text {th }}$ Dede Rosyada ${ }^{6}$ \\ \{putri.dwinovia17@mhs.uinjkt.ac.id ${ }^{1}$, Dewi.khairani@uinjkt.ac.id ${ }^{2}$, kamarusdiana@uinjkt.ac.id ${ }^{3}$, \\ kusmana@uinjkt.ac.id ${ }^{4}$, sururin@uinjkt.ac.id ${ }^{5}$, dede.rosyada@uinjkt.ac.id ${ }^{6}$ \}
}

Sy arif Hiday atullah State Islamic University of Jakarta, Indonesia ${ }^{1,2,3,4,5,6}$

\begin{abstract}
The emergence of the global Covid-19 pandemic has led to changes in learning activities that were initially carried out face-to-face to being completely at home, of course affecting changes in college students' information-seeking behavior, who can usually use printed information sources to become all digital. For this reason, this research was conducted to be able to find out how the information-seeking behavior of college students at Bukit Parung Asri Housing in fulfilling the need for lecture information during the pandemic. The method used in this research is a qualitative method with data collection techniques through interviews and literature studies. Based on the results of the study, it can be concluded that college students who live in Bukit Parung Asri Housing tend to be more able to implement electronic collections rather than printed ones and have information-seeking behavior that is by David Ellis' search behavior model theory. During the search process, there were obstacles to the internet network and also information sources that had limited access.
\end{abstract}

Keywords: Information Seeking Behavior, Information Needs, Pandemic, Covid-19

\section{Introduction}

As a social being, in all its activities, humans need information as a point in making interactions between individuals. Currently, the process of spreading information is increasingly experiencing an accelerated flow with the existence of information technology, where the exchange between information that surrounds humans is no longer tied to the existence of space and time. This is what causes the birth of complex information needs and must be fulfilled in every human being.

Information needs foster certain behaviors that characterize each individual in seeking information caused by a habit that occurs within the individual. Also, because certain circumstances can also cause the emergence of special characteristics in a group to have certain behaviors in seeking information. This is known as information-seeking behavior.

2020 is a situation in which the world is intensified with the Covid-19 (Corona Virus Disease) pandemic. This pandemic continues to spread throughout the world including Indonesia. As a result of this pandemic, various community activities have been forced to run inappropriately where all activities must be carried out at home. One of the impacts of this 
pandemic is learning activities in universities where students cannot study directly at the college they shelter or visit the library to get the information they need.

Tertiary Education Institution is an educational unit that organizes Higher Education. In carrying out its duties, universities have a group of students as students at the higher education level[1]. Students are a group of students who need information in fulfilling their educational needs, starting from doing assignments to adding insight into knowledge.

The Bukit Parung Asri housing located in Bojong Sempu village, Parung Bogor subdistrict is one of the housing estates where there are quite a several college students who have been affected by the covid-19 pandemic problem. This situation is a new thing experienced by college students at Bukit Parung Asri Housing in carrying out their lectures at home with all online systems to support their lectures. This has resulted in the growth of habitual changes in carrying out activities and daily lecture assignments.

Based on the problem in the problem described above, the author is interested in knowing more how about the information-seeking behavior of college students at Bukit Parung Asri residential community in fulfilling the information needs of their lectures during the pandemic.

\section{Research Method}

This study uses descriptive qualitative research methods. The descriptive research method is a research method that focuses on solving actual problems as they were when the research was carried out[2]. This research was conducted on college learners at Residents of Bukit Parung Asri by taking a sample of 3 people from the 20 student population who are the original residents of this housing. The research approach used in this research is qualitative. According to Wahidmurni, a qualitative research approach is a research method used to answer research problems related to data in the form of narratives originating from the interview, observation, document research [3]. Meanwhile, the data collection techniques used were interviews and literature studies. Then the data is reduced, displayed, and presented by research procedures. The descriptive data analysis model used in this research, described in Fig.1 below.

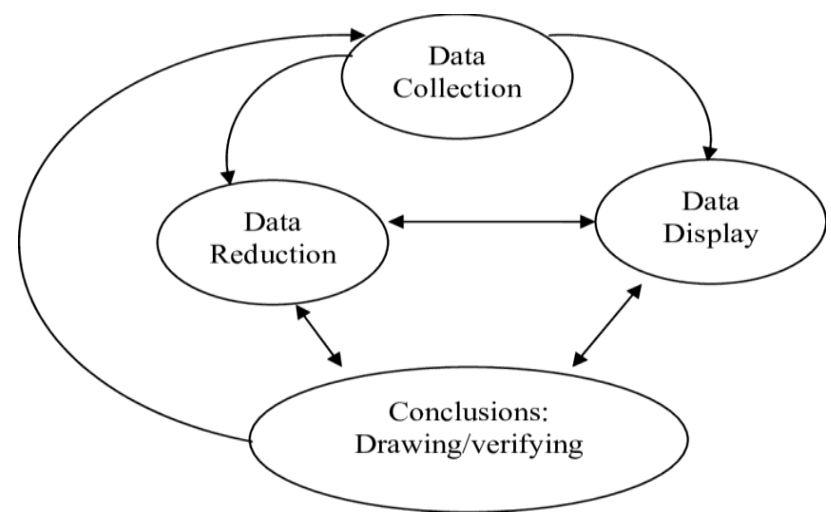

Fig. 1. Qualitative descriptive data analy sis model of Miles and Huberman[4] 


\section{Literature Review}

According to Belkin in Widiyastuti,[5] the need for information is a condition of one's knowledge about a certain situation or topic which is inadequate to deal with a situation. Information needs possessing by a person can vary from one another with the conditions and situations they face. With the growing need for information, information-seeking behavior arises in individuals. According to Spink \& Cole[6], information-seeking behavior is one of the areas of research in Library and Information Science which focuses on human information behavior related to information search and discovery strategies, information structuring, and information use.

The information-seeking behavior has various theoretical models put forward by experts. In this study, the authors used the information seeking behavior model proposed by David Ellis quoted by Donald O. Case in Riani[7], which consists of several stages, including: (1) Starting: start looking for information such as asking someone who is considered to have mastered a field of science in accordance with the information needed by individuals or accessing online catalogs and surfing the trusted web; (2) Chaining: examining the relationship citation of literature found at the time of "starting" and writing things that are considered important in small notes and linking any information or material that will be searched later; (3) Browsing: looking for relevant information, looking at primary and secondary literature, journals, table of contents, indexes, abstracts, and looking at websites from selected sources, or selected websites; (4) Differentiating: classifying literature, by author, quality or recency, marking important websites; (5) Monitoring: follow developments in areas of interest (regularly follow from certain sources in order to be up-to-date; (6) Extracting; selectively identify and seek relevant information on all material from certain sources, for example: all information on a particular topic on the selected web site; (7) Verifying: check the accuracy and correctness of information that has been found, especially information that comes from the web; (8) Ending: the end of the information search stage which is usually carried out in conjunction with the end of a research activity.

Research on information-seeking behavior has been carried out by several previous researchers. According to Siti Rozinah's [8] research, the source of information used by thesis writing students to meet their information needs is the main reference, journals as additional material, individuals from both school officials, religious leaders, fishermen, and students as informants/respondents, and articles that are downloaded from the internet. While the student information-seeking behavior model in thesis writing is by Ellis' model which consists of 6 (six) stages, namely starting, chaining, browsing, differentiating, monitoring, and extracting. However, from the 6 (six) stages, the 2 stages were not carried out specifically, namely monitoring and extracting.

According to Mulyadi's [9] research, the information-seeking behavior of UIN Alauddin Makassar students is driven by curiosity, self-actualization needs, and academic needs. To fulfill their information needs, students prefer printed information sources such as books, papers, and so on. Information seeking behavior is carried out by visiting libraries and bookstores. In searching for this information, students first check the relevance of information sources with their information needs, by looking at the table of contents, introduction, and introduction. Often there are several obstacles in seeking information, such as unavailability of the information required.

According to Latiar's[10] research, the information needs of disabled students at UIN Sunan Kalijaga Yogyakarta include information related to lifestyle, lectures, general, social life, health, and plans for the future. Meanwhile, in the analysis of information-seeking 
behavior, students with disabilities choose to fulfill their information needs by using the help of the internet instead of books. According to him, the internet is a source of practical and efficient information that can be accessed anytime and anywhere and provides a lot of information and entertainment.

According to Winarsih's[11] research, the information needs of 46 cadets at the Semarang Shipping Science Polytechnic Library is none other than to support their learning activities, such as writing theses, doing assignments, and add insight. In fulfilling their information needs, cadets look for this information in libraries and the internet. For their sources of information, they usually use books, journals, articles, and related previous theses. The information-seeking behavior of cadets is by David Ellis' information-seeking behavior model, starting from starting to end.

According to Rumata's[12] research, there is no significant difference between the information needs of urban and rural communities. In general, urban and rural communities have information needs related to the price of basic foodstuffs, the availability of basic commodities, the market where they can get basic foodstuffs to government policies related to food. To fulfill their information needs, the village community tends to rely more on television media or exchange information with neighbors. Meanwhile, urban people have used the internet to fulfill their information needs.

\section{Result and Discussion}

To find out how college students information-seeking behavior at residents of Bukit Paring Asri Housing in fulfilling the information needs of lectures during the pandemic, the authors interviewed the following person to gather the information:

Table 1. Sampling Interviewees.

\begin{tabular}{ccccc}
\hline No. & Name & College Name & Grade & Initials \\
\hline Fanny Montia & Fransiska & UPN Veteran Jakarta & 5 SMT & FMF \\
1. & $\begin{array}{c}\text { Faurizka Merza } \\
\text { Aulia }\end{array}$ & UIN Syarif Hidayatullah Jakarta & 5 SMT & FMA \\
2. & Nur Muzzamil & UIN Syarif Hidayatullah Jakarta & 5 SMT & NMS \\
3. & Fauzan Syarief & U. & & \\
\hline
\end{tabular}

\subsection{Information Needs}

Implementing an online lecture method at home still makes college students need the information to support their lecture activities. This is by the statements of the informants as follows:

"The information I need during this pandemic are matters related to the courses I take, such as family nursing practice, gerontic nursing practice, maternity nursing practice, and, mental nursing practice. Apart from looking for information related to courses, I am also looking for information about the development of Covid19, such as statistics on the 
spread of Covid19 in Indonesia and how to increase body immunity in the face of a pandemic "(FMF)

"The information I need is about information related to lectures and information about health in Indonesia" (FMA)

"Hmm ... I need information that I need is things related to the courses I take, such as information related to Educational Psychology, which this course needs more information. Besides that, I also like to look for information such as developments and the latest news information that is interesting and important to know. "(NFS)

Based on the statements of the three informants above, it can be seen that the information needs experienced by students who are residents of Bukit Parung Asri Housing are generally about information related to college learning activities followed by information about the latest news on the development of Covid-19 as well as the latest interesting and needed news info.

To the information needs of each individual of course there are types of information formats that are most needed and selected. The informant's statement regarding this matter included:

"The type of information I need most in a pandemic like this is certain information in electronic formats such as e-journals, e-books, and other articles." (FMF)

"Books, e-books, and e-journals. Yes, I still like to use it in printed form because it's more fun to read right away, and it hurts my eyes if I read it overtime on my laptop. Same for ebooks, sometimes the chapter is not complete. Usually, if it's a pandemic like this I buy it at an online shop sis "(FMA)

"What is certain is that information is of a digital type. What's more, in a state of the Covid19 pandemic, we can't go anywhere because we have to be at home, while printed sources have to be taken through the library so they can't be accessed or obtained easily so they are less reliable. "(NFS)

Based on the statements of 3 informants above, it can be seen that the type of information format needed during this pandemic is generally electronic or digital information such as ejournals, e-books, articles, and so on with reasons that are more reliable and easily accessible. However, it is also possible that printed collections will not be used during this pandemic, considering that some people cannot escape the habit of using printed information.

\subsection{Information Seeking Behavior}

In conducting his research, the researcher refers to Ellis' information-seeking behavior theory model which consists of several stages, namely Starting, Chaining, Browsing, Differentiating, Monitoring, Extracting, Verifying, Ending. The results of the research that the authors have done are as follows:

\subsubsection{Starting}

Starting is the stage where individuals start looking for information, for example asking someone who is an expert in one of the scientific fields that the individual is interested in. As in the informants' statements as follows: 
"To start the search for information, I usually before searching, prepare the topic of information first, and then search through the internet according to the topic that I specify." (FMF)

"First, I will make a list of information as the points to look for sis. So from there, sometimes I usually get the topic right away, but if I don't get it I'll also ask my friends. "(FMA)

"Usually I immediately determine the topic that will be discussed first, as if there is a lecture assignment, it is told what to look for, even from there only about the right keywords that fit what topic so that it is easy to search on google." (NFS)

Based on the statements of the 3 respondents above, it can be seen that during the Covid 19 pandemic, the majority of college students who were residents of Bukit Parung Asri Housing began searching for information by determining the topic of the problem first before searching.

\subsubsection{Chaining}

Chaining is the stage where someone tries to connect the information they need with what they are looking for. This is by the statements of the informants below:

"I usually just enter keywords into search engines. So after that I searched from several sources, not just one because it can be an additional reference for the information I want to find"(FMF)

"I look for information by writing down keywords and then I take it from various sources so that I can better understand a material. Besides, it can also complement if one source is incomplete."(FMA)

"Hm .. I usually enter keywords into the search engine that have been obtained from the topic to be searched for, do searches on reliable sources such as electronic journals, google scholarships, repositories, and e-books. I will check almost all the data that appears to see if the keywords I enter or the material I am looking for are correct or not. Usually, I read 1-5 articles as a comparison and as a variety of information that I will get."

Based on the three informants' statements above, it can be seen that generally college students who are residents of Bukit Parung Asri Housing already know the topics to be searched for in conducting information searches so that they will immediately search with search engines or directly search e-journals and e-books using the appropriate keywords with the topic of information they are looking for. In also, they also conduct information searches from various sources of information to obtain an overview of their information needs.

\subsubsection{Browsing}

Browsing is an activity to find structured or semi-structured information. Generally have their style in carrying out the information-seeking process. The informants' statements regarding this included:

"Directly type in the keyword information that $i$ want to find in the search engine column."(FMF) 
"Usually when I browse I use google and the file type is pdf." (FMA)

"Hmm ... I use the google scholar search engine to make it easier to search for academic matters. Usually, I use restrictions by adding format (pdf)." (NFS)

Based on the three informants' answers above, it can be seen that during the Covid-19 pandemic, college students who were residents of Bukit Parung Asri Housing had their way of doing searches on the internet. However, on average they limit the file type/format when performing searches to meet their information needs to make the search process easier.

\subsubsection{Differentiating}

Differentiating is a stage in selecting which data to use and which ones are not necessary. This stage is the fourth stage of information-seeking behavior activities. The informants' statements regarding this stage include:

"When I get some information, I usually compare it from one source to another. If there is a match usually I will use the information. However, if there are no similarities from some of these sources, I will try to find other information so that I can get more valid and accurate information." (FMF)

"I will sort it out by doing a quick reading of a journal/book if it is related to what I am looking for. I choose that. The reason is that by reading quickly saves time and already knows the point."(FMA)

"I will compare one source with other sources that I have found to find a match with my needs. Usually, by doing this, I get more information than one of them, so if it matches both information and what I'm looking for. I will use it. However, if there are no similarities from some of these sources, I will try to find other information again."(NFS)

The statements of the informants above show that to meet their information needs during the Covid-19 pandemic, the majority of college students who are residents of Bukit Parung Asri Housing sorted out the information they got. This shows that during the information retrieval process, they do not immediately use it, but sort it out first by comparing and reading quickly the information obtained whether it is by the needs of the information they are looking for.

\subsubsection{Monitoring}

Monitoring is the process of monitoring or looking for the latest information. The most recent information on search results is usually indicated by the year the information was born. As the informant's statement is as follows:

"Usually, to get updated information, especially about nursing, I will take information through e-journals about nursing and e-books and choose the most recent one. Moreover, there are usually a lot of journals that are always updated on the internet. If it's about Covid-19, that's a lot, yes, every day there is always news about Covid either on the internet or TV. "(FMF)

"I took information through E-journals and the internet to update information on both learning and Covid-19."(FMA) 
"What is certain is that I get information through e-journals and several online mass media such as Detik.com and CNN Indonesia. Because news is easier to pass through this media so the latest news will appear quickly. "(NFS)

Based on the opinion of the three informants above, it can be seen that generally college students who are residents of Bukit Parung Asri Housing use journals and also the internet as a medium to monitor the information they need both for information purpos es for lectures and the latest news about COVID-19.

\subsubsection{Extracting}

This stage is the stage where individuals have started to take or select the information that they consider important and can be used as data for their research or assignments by taking from one trusted source. This is by the opinion of the informants, including:

"How to identify sources of information that I get to avoid hoaxes and updates as well, of course, I will look at the search portal which has proven its validity and relevance, in addition to matching the information findings with the topic of search needs. Besides that, if there is someone who is qualified in the topic I am looking for, I usually ask him or her. "(FMF)

"Usually to get the most up-to-date and quality information I will only seek information from official websites such as the Ministry of Health, NCBI which is proven and relevant." (FMA)

"Hmm .. what is it? Usually, the way I identify the sources of information obtained and avoid hoaxes, I will sort out the existing information as needed and also always match the information with others. Usually, I study from the many sources that raise this information. besides that, I usually ask back with friends who are quite up to date for information to know their views on this matter." (NFS)

Based on the opinion of the informant above, it can be seen that generally students of Bukit Parung Asri Housing identify information by choosing sources of information as needed on tested and up-to-date information sources both in journals and official websites and discussing with friends or people. who understand the topic he is looking for. This is also done to avoid hoaxes or false information.

\subsubsection{Verifying}

Verifying the stage where individuals check the materials they have collected. The informant's opinion regarding this matter included:

"Usually I will open the information and if there are many pages to read, I will look for keywords that I enter on search engines into the file to save time too. But if there is only a little to read, I will read the whole. "(FMF)

"No, I didn't check again. What is important for me, I get the information I need. "(FMA)

"Yes, I will check again whether it is valid or not. Usually, I ask my friends and sort out which of my friends' answers are almost the same as the information I get. And also looking for other sources related to the information I got." 
Based on the informant's statement, it can be seen that on average college students who live in Bukit Parung Asri Housing double-check the information that has been obtained.

\subsubsection{Ending}

The ending is the final stage of the information retrieval process where the individual carries out final checks and also presents the information by the rules or rules for writing information sources. The following are the opinions of the informants regarding this matter:

"I will read and evaluate by asking a more qualified person on the problem to get more accurate information." (FMF)

"After getting the information, I will usually read again and make notes on the main points of the problem or the information I need to make it easy to present."(FMA)

"I will sort and match the information I have obtained so that it validates the information and I immediately use the information to become material to make assig nments as needed. When finished using the information, I will usually save the information file. Maybe sometimes it can be used again. "(NFS)

Based on the opinion of the three informants above, it can be seen that college students who are residents of Bukit Parung Asri Housing are searching for the truth about the information that has been obtained, asking those who are more familiar with the information and also storing the information that has been obtained so that one day it can be reused.

\subsection{Obstacles}

In carrying out information searches, generally, each individual has certain obstacles he has experienced, especially during this pandemic. This is by the statements of the informants as follows:

"Because now many use the internet and digital formats, usually problems arise, such as slow internet. To overcome this, I usually turn off internet data and then turn it back on." (FMF)

"The obstacles I face are that I look for the website of the Ministry of Health, sometimes the files from the Ministry of Health cannot be opened, many journals use English, and it is difficult to find the right keywords for the information I want to get. To overcome this problem by looking for other sources not only the Ministry of Health, translating it even though it requires a lot of time, and for keywords, I usually ask friends who have found the information they need." (FMA)

"The obstacle I face in searching for information is the weakness of the internet and the network which sometimes happens at certain times, such as power outages when I am looking for information. This searches for information takes longer and can also stop. Besides, some sources are not openly accessible. The solution is to do the task when the network is good and from far away and look for other sources that can open access." (NFS) 
Based on the informant's statement above, it can be seen that the obstacles faced by college students who are residents of Bukit Parung Asri Housing generally occur on slow internet network connections and also limited access to the information needed.

The efforts made to address the problems experienced are by doing tasks and accessing the information needed when the network is good or turning off internet data and turning it back on which sometimes will have a good effect on the quality of the internet network used. Besides, to overcome the limited access to information needed, students will look for information from other sources to find one that suits their needs.

\section{Conclusions}

Based on the explanation in the previous chapter, the conclusions from the research results that have been obtained are:

The information needs of college students who are residents of Bukit Parung Asri Housing during the pandemic are generally related to information on lecture learning activities followed by information on up-to-date news on the development of Covid-19 and the latest interesting and needed news info. The sources of information used are electronic or digital sources of information such as e-journals, e-books, articles, etc. for reasons that are more reliable and easily accessible during a pandemic. However, it is also possible that printed collections will not be used during the pandemic, considering that some people cannot escape the habit of using printed information.

The information-seeking behavior of students of the Bukit Parung Asri housing community in fulfilling their information needs has differences between one another. However, the authors concluded that the majority of these students carried out the information search process through 8 stages of David Ellis' search behavior model, namely starting, chaining, browsing, differentiating, monitoring, extracting, verifying, and ending.

The obstacles faced by college students who live in Bukit Parung Asri Housing in fulfilling the need for lecture information during the Covid-19 pandemic are the internet network which often experiences problems or slow connections and some of the information sources obtain ed have limited or paid access.

Acknowledgments. This paper was supported by PPM UIN Syarif Hidayatullah for KKN-DR year 2020. 


\section{References}

[1] R. Indonesia, "Undang-Undang Republik Indoensia No.12 Tahun 2012 Tentang Pendidikan Tinggi," no. 1, 2012.

[2] T. Soendari, Metode Penelitian Deskriptif. Bandung: UPI. Stuss, Magdalena \& Herdan, Agnieszka 17, 2012.

[3] Wahidmurni, Pemaparan Metode Penelitian Kualitatif. Malang: UIN Maulana Malik Ibrahim, 2017.

[4] M. Miles and A. Huberman, "Miles and Huberman Chapter 2," in Qualitative Data Analysis, 1994.

[5] Widiyastuti, "Perbandingan Teori Pelaku Pencarian Informasi MENURUT ELLIS, WILSON DAN KUHLTHAU,” Inf. Sains, vol. 3, no. 2, pp. 51-64, 2016.

[6] A. Spink and C. Cole, "Human information behavior: Integrating diverse approaches and information use," J. Am. Soc. Inf. Sci. Technol., 2006, doi: 10.1002/asi.20249.

[7] N. Riani, "Model Perilaku Pencarian Informasi Guna Memenuhi Kebutuhan Informasi (Studi Literatur)," Publ. Libr. Inf. Sci., vol. 1, no. 2, p. 14, 2017, doi: 10.24269/pls.v1i2.693.

[8] Siti-Rozinah, PERILAKU PENCARIAN INFORMASI MAHASISWA DALAM PENULISAN SKRIPSI (Studi Kasus di Sekolah Tinggi Agama Islam Nahdlatul Ulama (STAINU) Jakarta) TESIS. Depok: Universitas Indonesia, 2012.

[9] I. Muliy adi, "Perilaku Pencarian Informasi Mahasiswa Pascasarjana UIN Alauddin Makassar," Khizanah al-Hikmah J. Ilmu Perpustakaan, Informasi, dan Kearsipan, vol. 6, no. 1, pp. 1-11, 2018, doi: $10.24252 /$ kah.v6i1a1.

[10] H. Latiar, "Analisis Kebutuhan dan Perilaku Pencarian Informasi Mahasiswa Difabel UIN Sunan Kalijaga Yogyakarta," Libr. J. Perpust., vol. 6, no. 2, pp. 239-256, 2018, doi: 10.21043/LIBRARIA.V6I2.2767.

[11] S. A. Winarsih, "KEBUTUHAN DAN PERILAKU PENCARIAN INFORMASI TARUNA ANGKATAN 46 DI PERPUSTAKAAN POLITEKNIK ILMU PELAYARAN SEMARANG," vol. 2, 2013.

[12] V. M. Rumata, "Perilaku Pemenuhan dan Peny ebaran Informasi Publik Bagi Masyarakat Kota dan Desa," J. Penelit. Komun., vol. 20, no. 1, pp. 91-106, 2017, doi: 10.20422/jpk.v20i1.146. 